\title{
Arthropod Diversity and Distribution; How do the NRCERS Agricultural Procedures Impact?
}

\author{
Islam Mohammad Zidan
}

National Research Centre (NRC), Agricultural and Biological Research Institute, Pests and Plant Protection Department. El-Bohouth St, Dokki, 12622 P.O., Giza, Egypt.

\begin{abstract}
The National Research Centre's experimental research station (NRCERS) locates in Wadi El Natrun, Egypt 30²9'54.22"N 30¹9'10.94"E. The NRCERS has various crop yields (vegetables, fruits, ornamental, and field crops) for different experimental treatments. It followed conventional agricultural procedures in vegetation, fertilisation, irrigation, and plant protection. Such policies have not been evaluated for their impacts on arthropod diversity and distribution. Thus, this study conclusion aims to sufficiently map the arthropod species (pest/predators) distribution, measure the biodiversity indices, to the NRCERS agricultural policies to be modified to support arthropod diversity.
\end{abstract}

Keywords: Insects; Acari; Araneae; Gastropods; Weeds; Pesticides; Fertilizers; IPM; ArthropodPlant Interactions; Tri-trophic relationship

\section{Background}

Invertebrates are important indicators of soil health and quality, not only for economic crops and trees but also for humans (Stork and Eggleton, 1992; Wall et al., 2015; Barreto et al., 2021). Arthropods, as an example, are good indicators in both terrestrial (Behan-Pelletier, 1999; Orlofske, 2008; Abdul Maleque et al., 2009), and aquatic ecosystems (Sleem and Hassan, 2010; Goldschmidt, 2016). These organisms could measure environmental, biological, and ecological changes, like climate change, which significantly affect public health, agriculture, water supplies, energy production, and land use and development (EPA, 2021). Within soil and/or Agro- ecosystems, the interactions among this enormous group diversified (Wardle, 2006), e.g., arthropod-arthropod (Polis et al., 1989; Schausberger, 2003; Wang et al., 2019) and arthropod-plant interactions (Dicke and Sabelis, 1988; Cuny et al., 2021; Meijer et al., 2022). Other invertebrates, as gastropods, that reported to be pests for either field crops and vegetables (Desoky, 2018), or ornamentals and fruits (Eshra, 2013), however, Barker and Efford, (2004) have mentioned the predacious gastropods that are used to control molluscan and other invertebrate pests.

According to the European Commission and the Global Soil Biodiversity Initiative (Orgiazzi et al., 2016) Egypt is in the arid/semi-arid climatic zone, which has moderately large annual temperature ranges between $18-28^{\circ} \mathrm{C}$, with less than $250 \mathrm{~mm}$ of annual rainfall, the soil temperature regimes classified as Hyperthermic; that mean annual soil temperature (MAST) $\geq 22^{\circ} \mathrm{C}$ and difference between mean summer and winter soil temperatures $\geq 6^{\circ} \mathrm{C}$, and Megathermic the mean annual soil temperature is larger than $28^{\circ} \mathrm{C}$. These climatic fluctuations have massive significant influences on soil-forming processes, and therefore its biodiversity. As well, Egypt which is vulnerable to water shortage (Omar and Moussa, 2016; Kansara et al., 2021), the consequences of water scarcity are hypothesised to eliminate arthropod diversity (Prather et al., 2020), and that would be an extra stress for the biogeographic distribution in newly reclaimed areas. Since the mid-50s of the $20^{\text {th }}$ century, the increase in agricultural production through horizontal expansion and reclamation of new lands was a large objective of the Egyptian Government (Wolf, 1993). Because 
of the GERD filling crisis, one of the prospected filling scenarios is the land loss, Heggy et al., (2021) have analysed that 5,344,180 feddan would be lost after three years of filling.

\section{The NRCERS}

The NRCERS locates in Wadi El Natrun, El Behera Governorate (GCS 30²9'54.22"N 30¹9'10.94"E; $23 \mathrm{~m} \mathrm{BSL),} 50 \mathrm{~km}$ western Nile (Rasheed branch), $110 \mathrm{~km}$ southern Alexandria, and $120 \mathrm{~km}$ north of Cairo. The station's total area is about 584,387.18 $\mathrm{m}^{2}$ (140 feddan), divided into sections, each for a different kind of experimental crop plantation (Fig. 1).

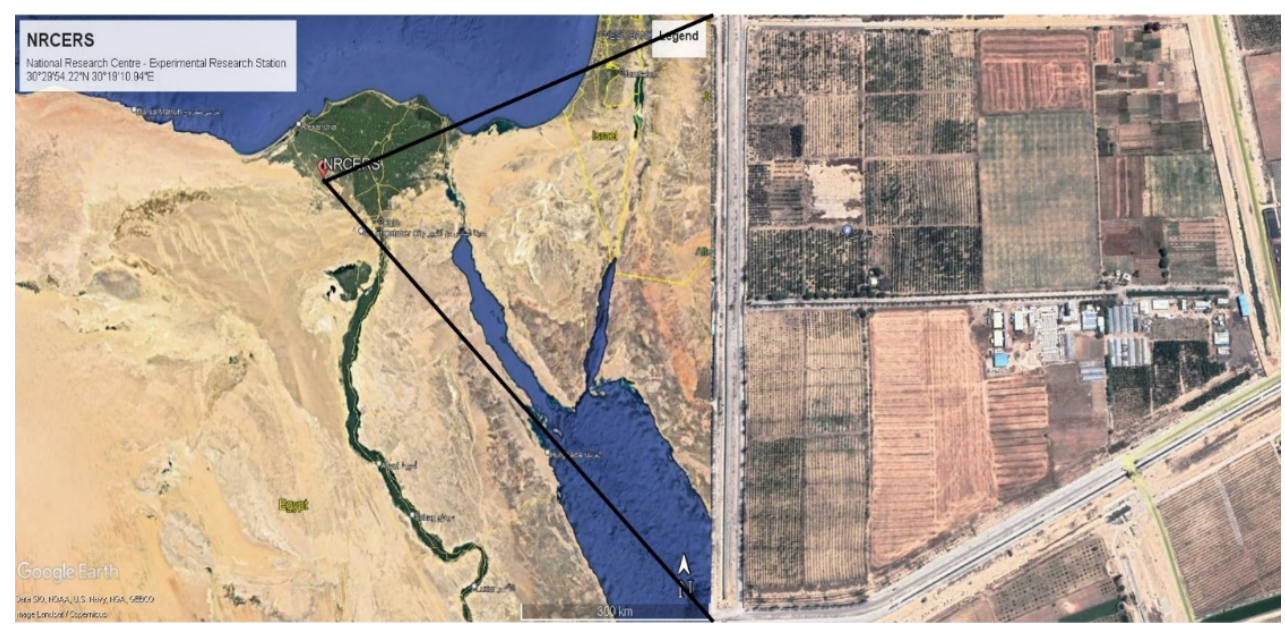

Figure 1. The NRCERS location.

Egypt's agricultural total cropland area (feddan) was increased by $16.55 \%$ since 2000 . The total fertilizers usage (tonnes) increased for N (16\%), P2O5 (44.83\%), K2O (285\%), and the fertilizers use per area $(\mathrm{kg} / \mathrm{ha})$ indication had significant changes of $\mathrm{N}$ which decreased by $0.5 \%$ while increasing reported in case of $\mathrm{P} 2 \mathrm{O} 5(24.26 \%)$, and $\mathrm{K} 2 \mathrm{O}(230.20 \%)$ during these 20 years. Organic manure that applied to soil $(\mathrm{kg})$ was highly increased; for chickens $(92.23 \%)$ and cattle (30.33\%) manures. The total pesticides usage (tonnes) was increased; insecticides $(72.72 \%)$ and herbicides $(268 \%)$, also the indication of pesticides usage $(\mathrm{kg} / \mathrm{ha})$ was positively enlarged by $129 \%$. These indications led to a climate change that affected the Egyptian temperature $\left({ }^{\circ} \mathrm{C}\right)$, which had increasingly raised by $1263 \%$ (FAOSTAT, 2021). A proposed timeline maps from 1985 till 2022 generated using Google Earth (Pro 7.3.4.8248 Beta, https://www.google.com/earth/index.html) have showed significant differences in location structure, due to climatic and human activities changes (Figs. 2-6).

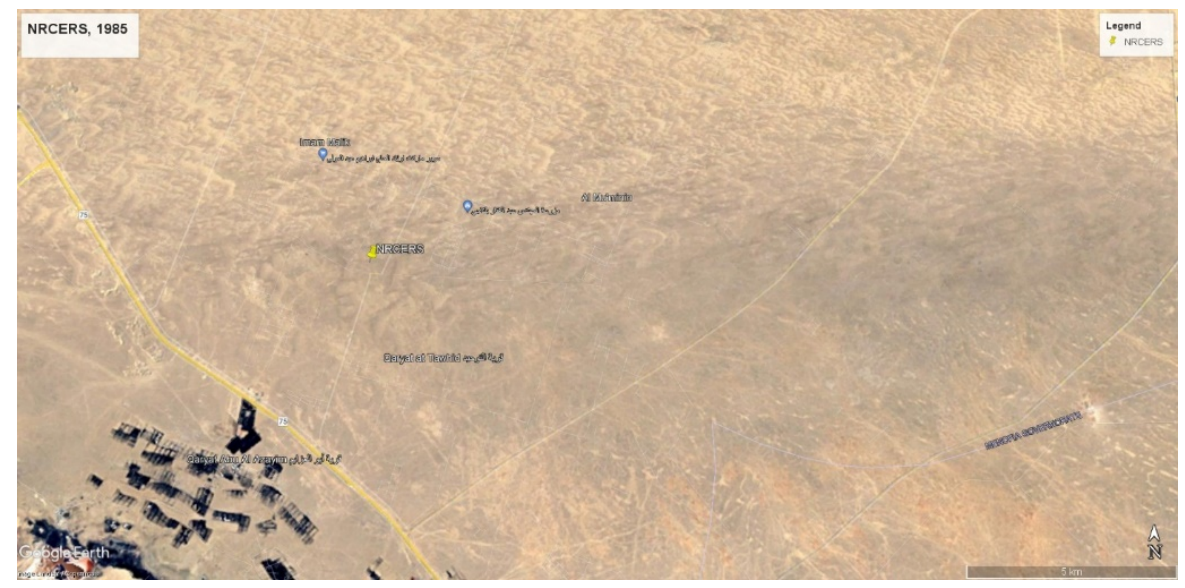

Figure 2. The NRCERS location, 1985. 


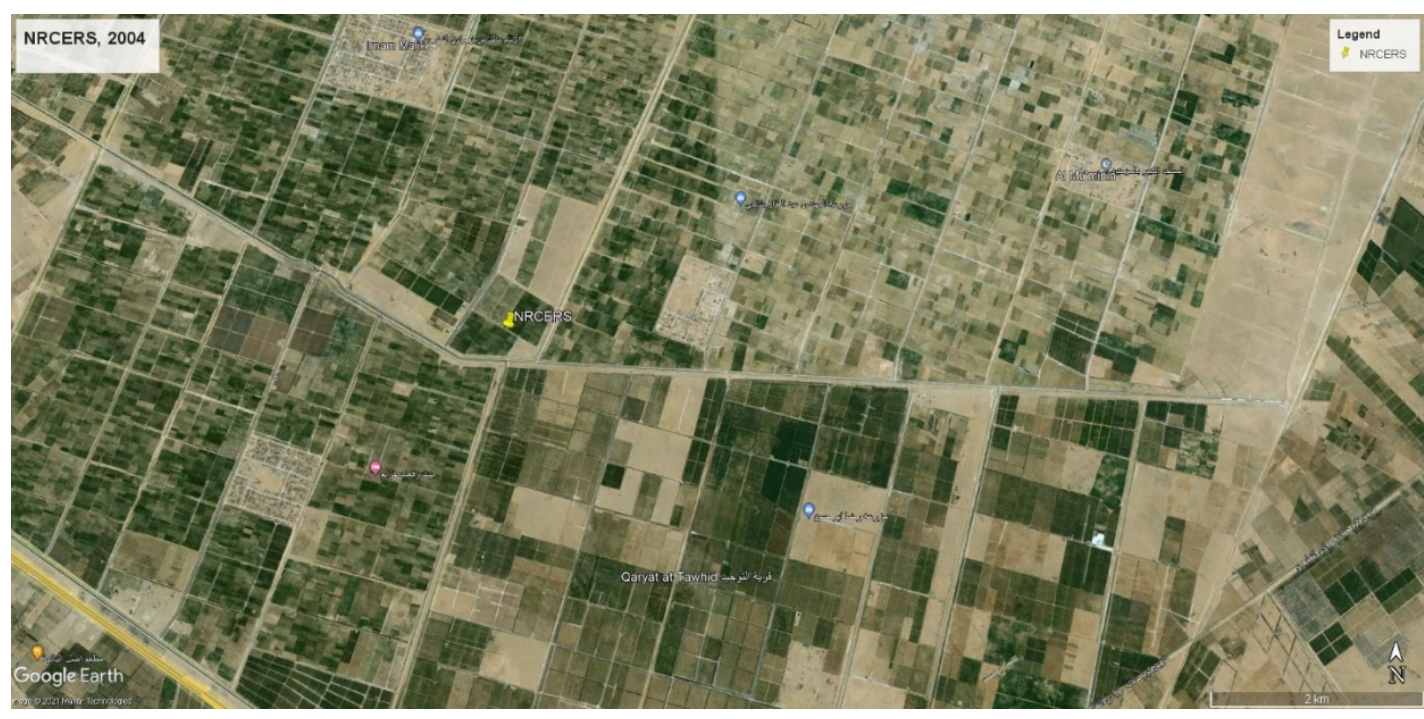

Figure 3. The NRCERS location, 2004.

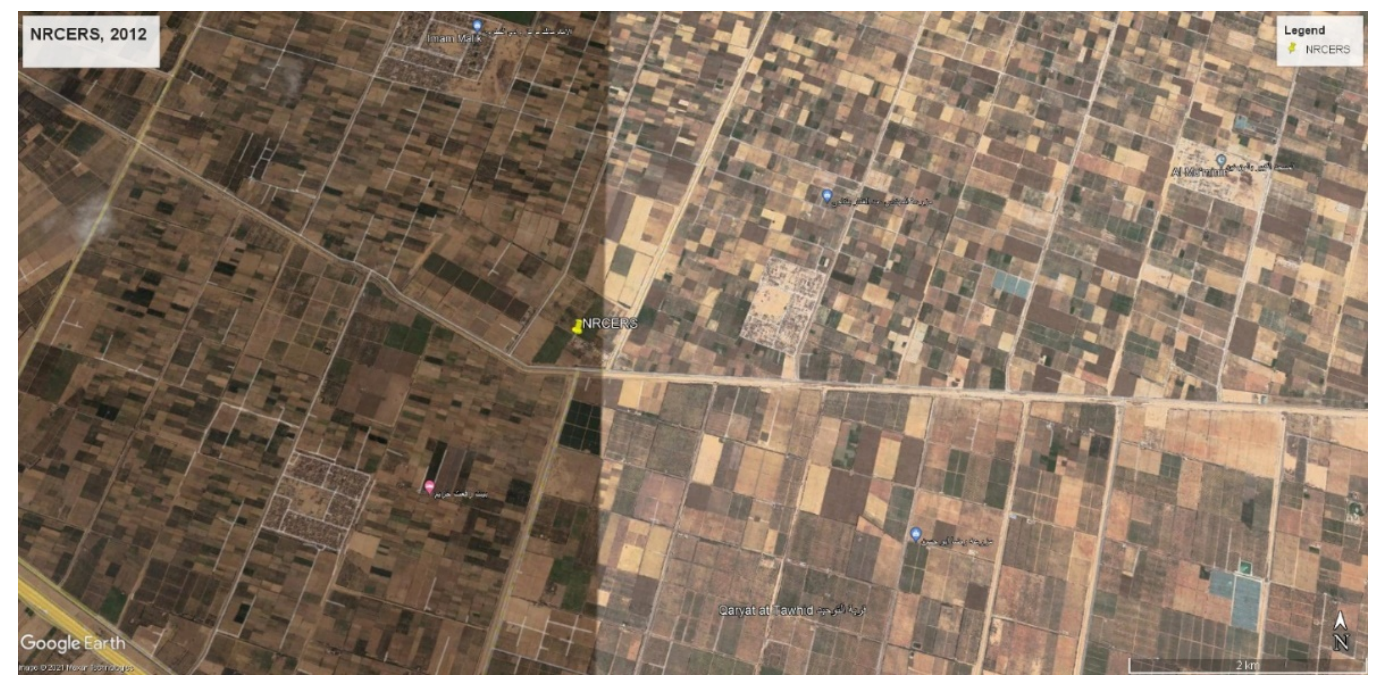

Figure 4. The NRCERS location, 2012.

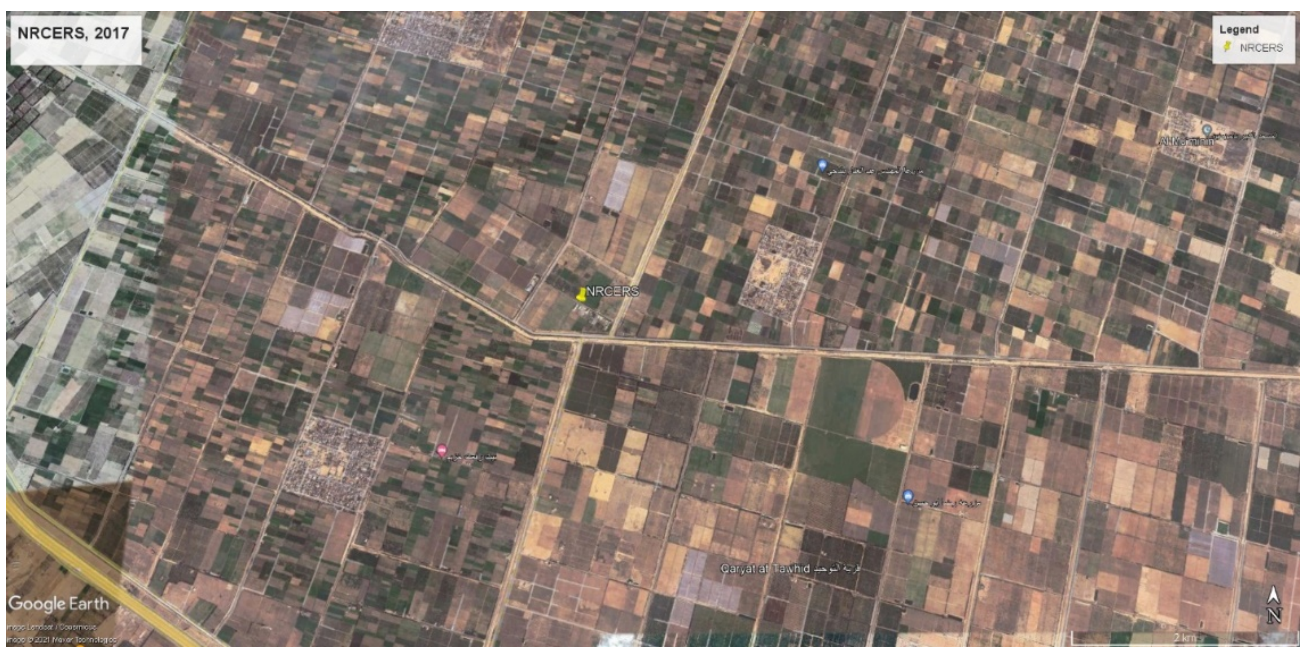

Figure 5. The NRCERS location, 2017. 


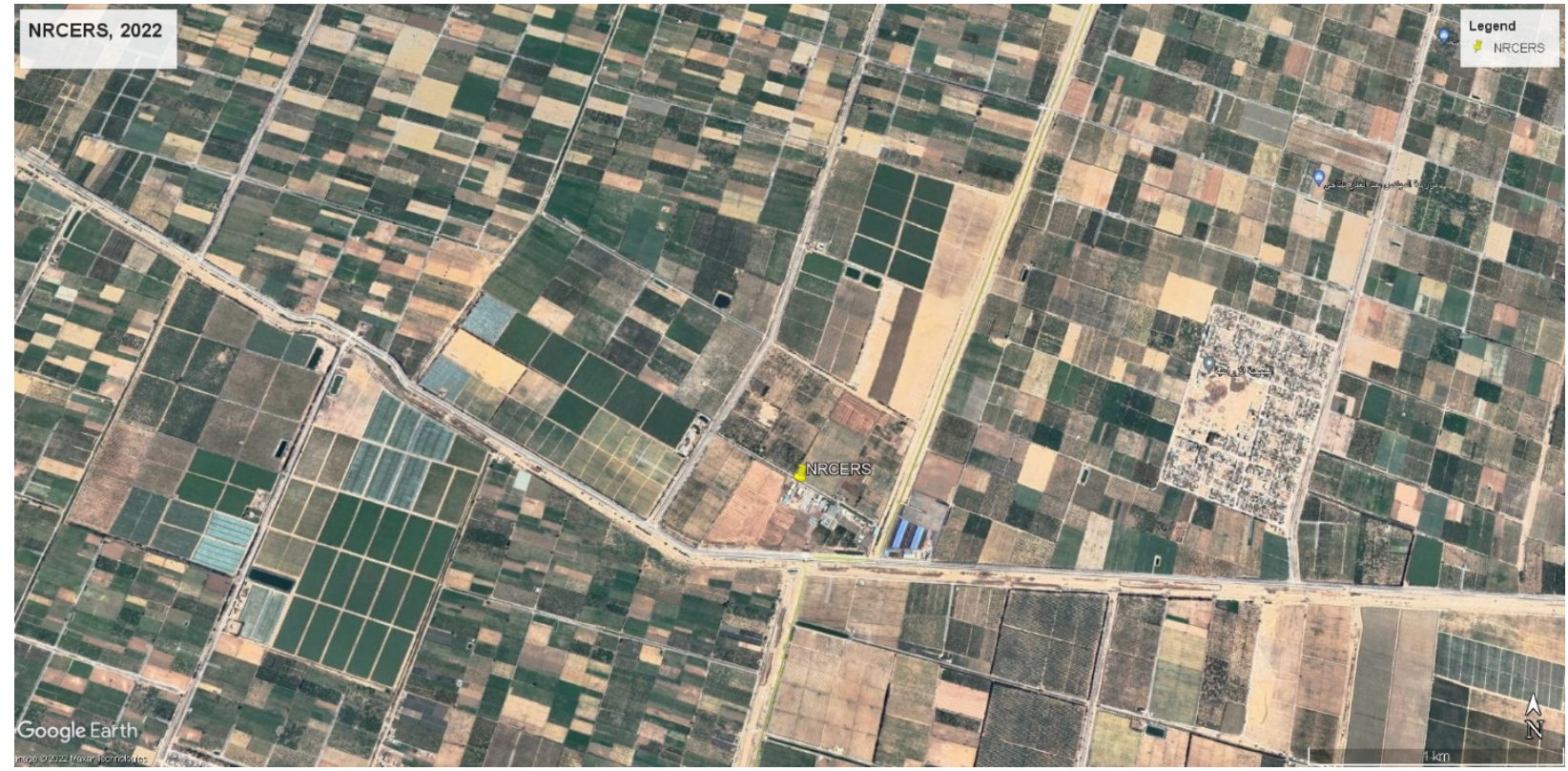

Figure 6. The NRCERS location, 2022.

Prather et al., (2020) reported that arthropod diversity and abundance have been significantly affected due to drought and other abiotic stress factors, as well as biotic factors (Orlofske, 2008). Theoretically, such factors shift the Agro-ecosystem into desert-ecosystem over time, thus, alternative agriculture policies must take place instead of conventional agriculture (Omar and Moussa, 2016).

Historically, the first published biogeographical map has described the botanical distribution of France, in the 3rd edition of the "Flore française" by Lamarck and Candolle in 1805 (Ebach and Goujet, 2006). Little is known about the biogeographical distribution of invertebrates, however, a lot of published data about Egyptian phytogeographical diversity and distribution in oases, deserts, and newly reclaimed areas since the beginnings of the 20 ${ }^{\text {th }}$ century (Hassanein Bey, 1925; Boulos, 2000; Abd El-Ghani and El-Sawaf, 2004; Abd El-Ghani et al., 2008, 2013, 2017; Kaky and Gilbert, 2017; Abdelaal et al., 2020). Most of the cited literature on land reclamation concerned macro-scale consequences of cultivation and the complications of ensuring either adequate and sustainable water supply (Wolf, 1993; Adriansen, 2009; Tawfik et al., 2012), or other agricultural procedures (e.g., fertilizing) (Zeidan, 2007; Bakry et al., 2011, 2012).

Arthropod species diversity and distribution data in the NRCERS and/or Wadi El Natrun, were not rich enough to figure out the different trophic relationships in this new region. However, some studies at El Behera governorate have revealed the abundance, survey, taxonomy, and even control applications for mite (Abou-Awad et al., 2006, 2016, 2017; Nasr, 2016; El-Laithy et al., 2021) insect (Haggag et al., 2014; Adss and Tabikha, 2016; Salama et al., 2016; Alfazairy et al., 2020), and true spider (El-Naggar and Sallam, 2000; ElErksousy et al., 2018) phytophagous and predatory species, as well as some molluscan plant pests (Eshra, 2013). Besides, no published biogeographic data of these organisms' distribution.

Weeds are being distributed withing the NRCERS all over the year. Different species of weed taxa, which required to be controlled (NRCERS administration personal communications). The weeds do need to multiple usage of herbicides exclusively (Fig. 7-10). However, these weeds could interact as alternative shelters for predatory species that possibly existed. Weeds are acting essential role in similar ecosystems in Algeria (DeghicheDiab et al., 2016, 2020), and they must be managed not to be eliminated. 


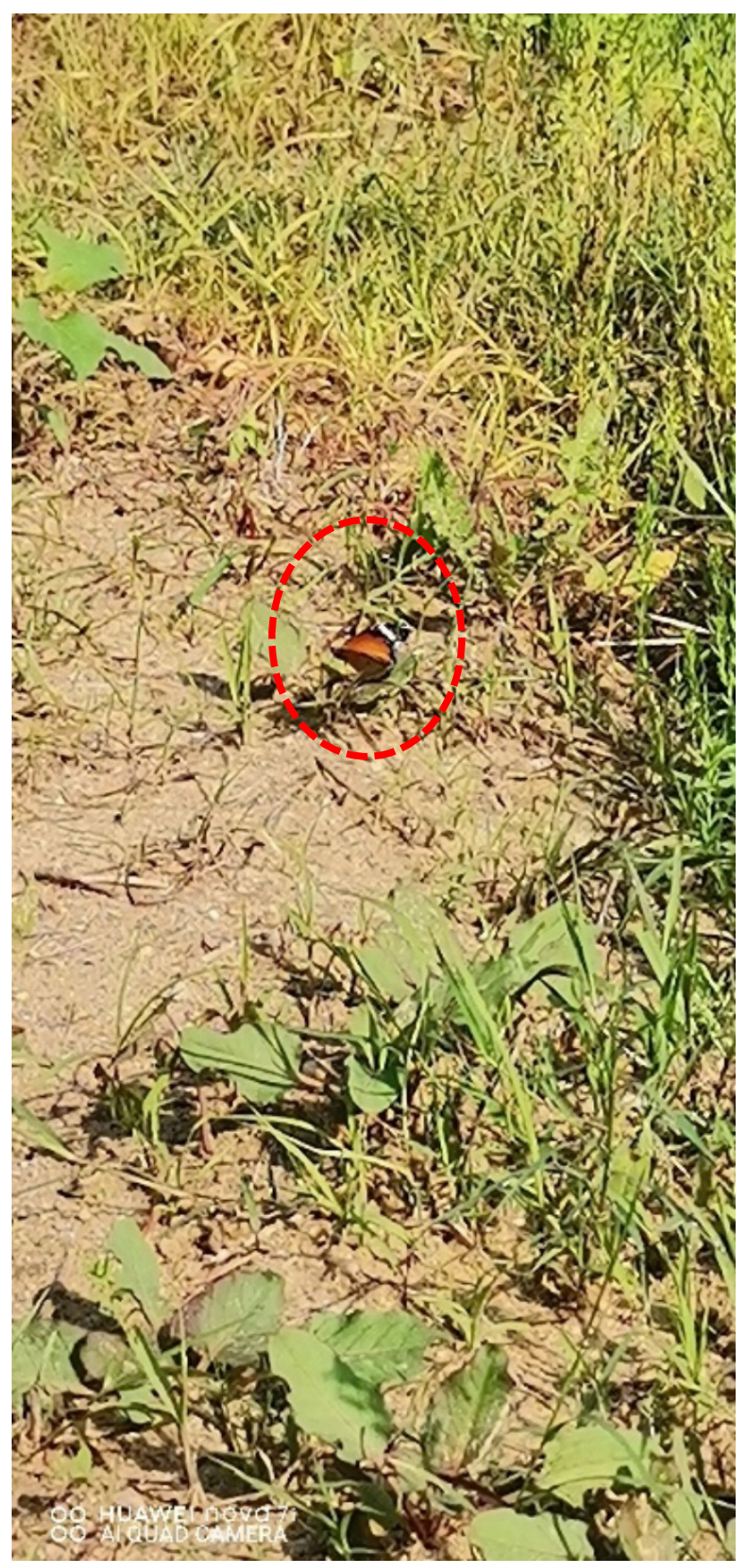

Fig. 7. The associated biodiversity in weed ecosystem, that being a shelter for lepidoprous insects (Photo credits: Dr. Zidan I.M., Oct 2021) 


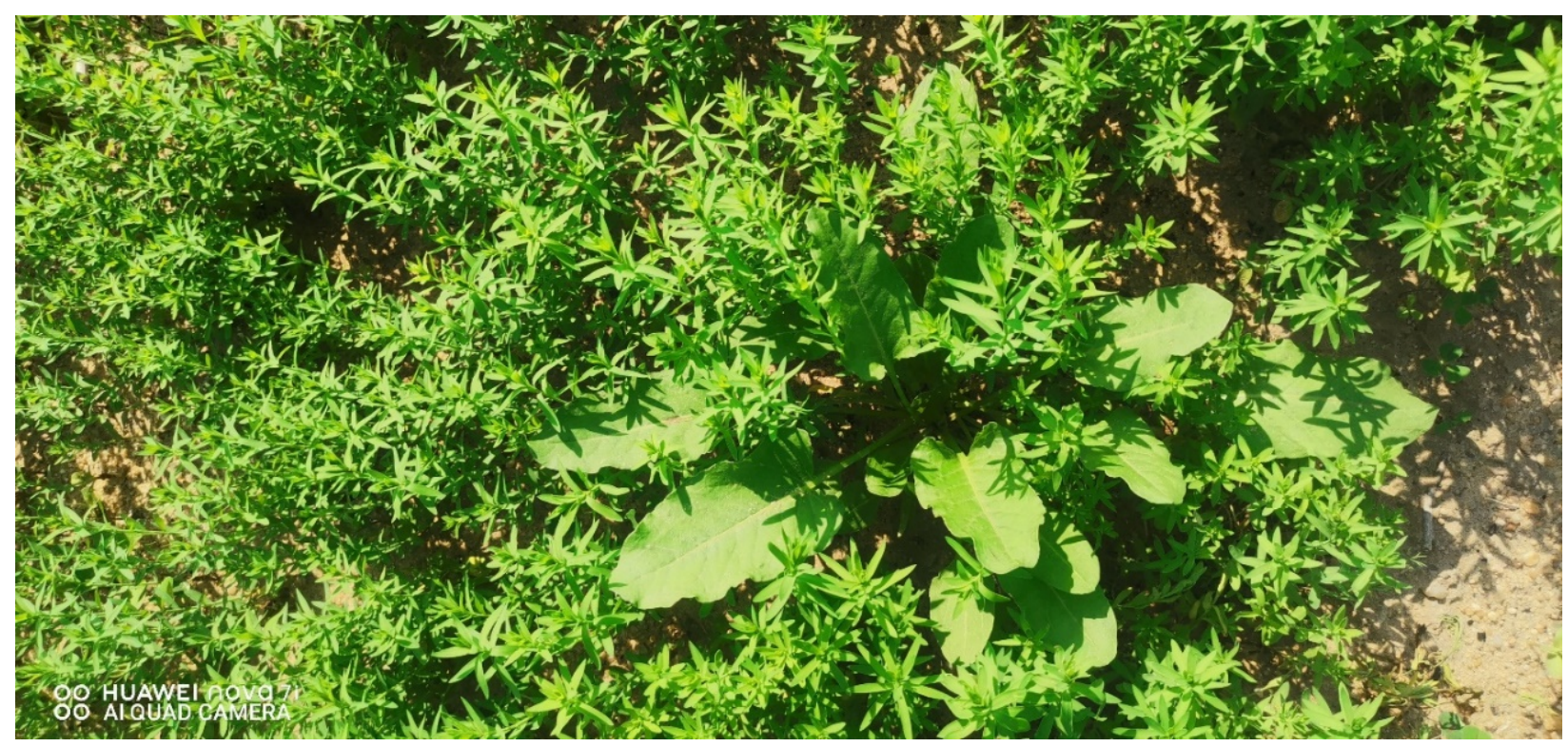

Figure 8. Weeds been parasitizing on flax plot (Photo credits: Dr. Zidan I.M., Dec 2021).

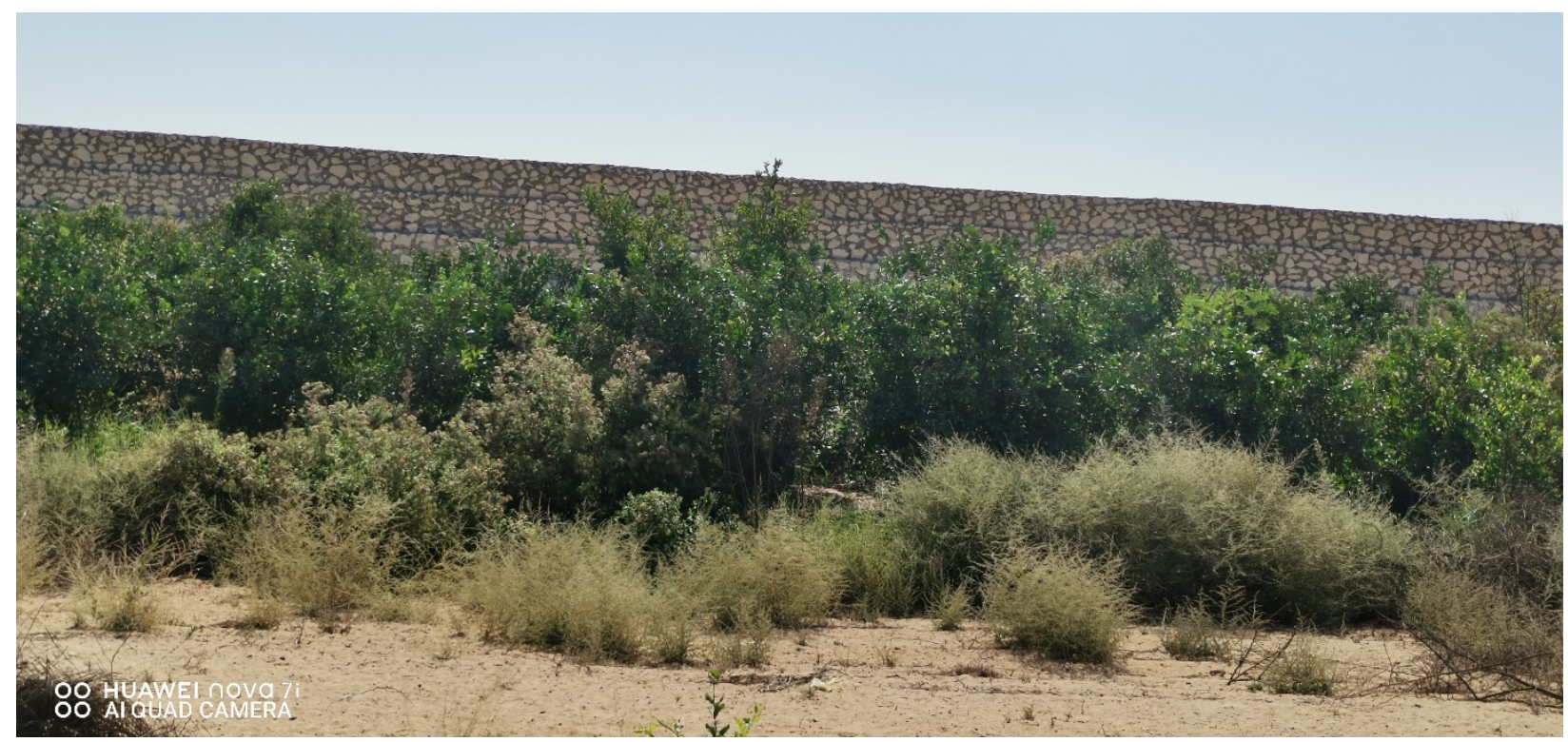

Figure 9. Massive weed clusters in citrus orchard (photo credits: Dr. Zidan I.M., Nov 2021). 


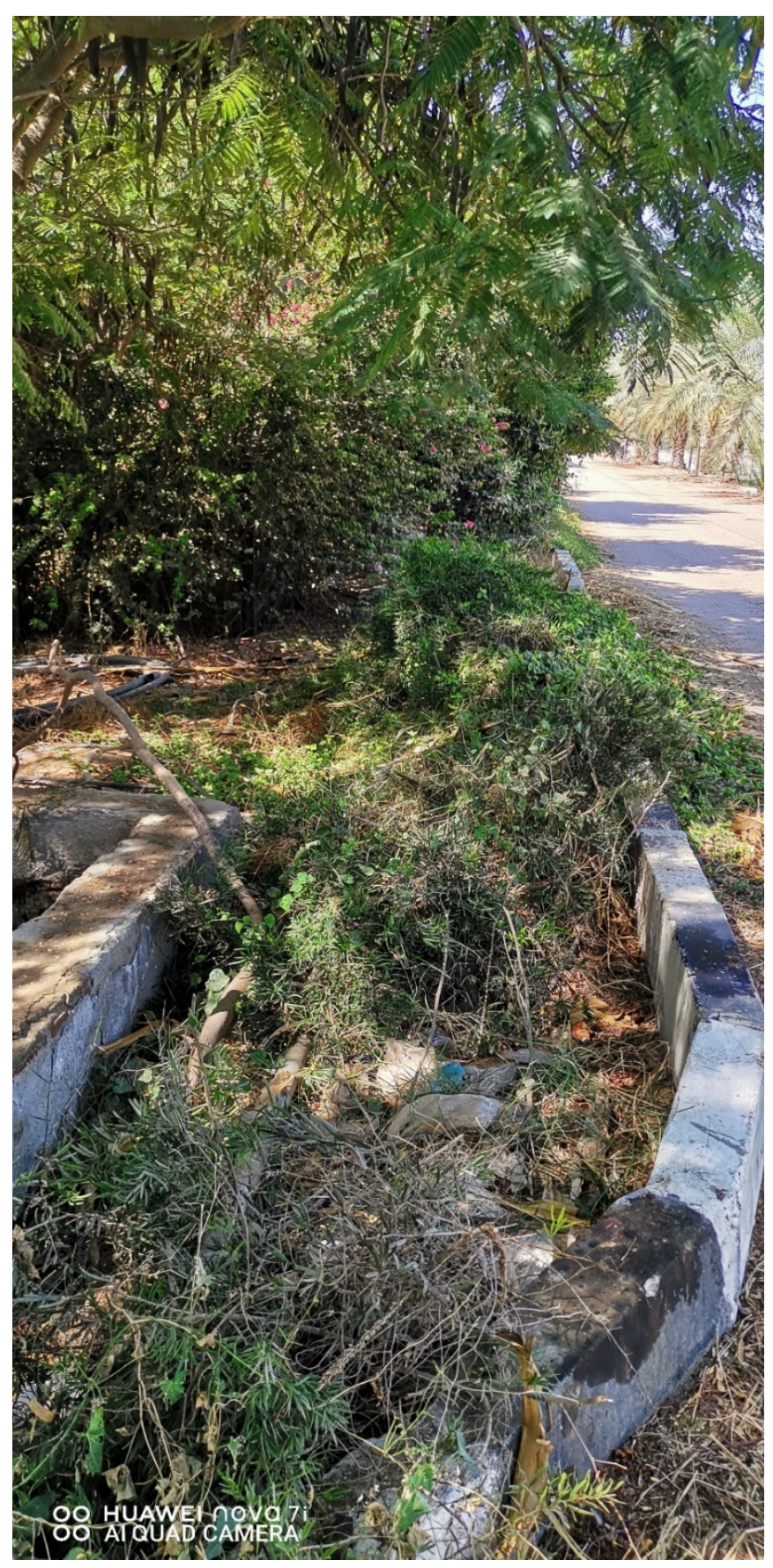

Fig. 10. Weeds of boarders and pavements, hypothesized an alternative ecosystem for both herbivores and predatory species (Photo credits: Dr. Zidan, I.M, Oct 2021).

\section{Conclusion}

FAO (2021) stated that the extreme use of mineral fertilizations and chemical compounds (e.g., fertilizers, pesticides) could led to nutrient imbalance. That would be reflects on the invertebrate diversity as; reduces soil microorganisms growth rates, decreases the nutrient flow, negatively impacts on the agro-ecosystem's food webs, changes the outcome products (e.g., vegetables, fruits, cereals) nutritional content. Thus, this article aiming sufficient biogeographic studies to be carried out, in order to introduce a map of arthropod species (pest/predators) distribution, projects to measure the biodiversity indices of these organisms, and to the NRCERS agricultural policies to change, on order to support arthropod diversity. 


\begin{abstract}
Abbreviations
NRCERS: National Research Centre experimental research station, IPM: Integrated Pest Management, TSSM: Two-spotted spider mite, GCS: Geographic coordination sys-
\end{abstract} tem, BSL: Below sea-level, GERD: Grand Ethiopian Renaissance Dam,

Declarations: Ethics approval and consent to participate Not applicable.

Consent for publication: Not applicable.

Availability of data and material: Data available upon request.

Competing interests: Author declares there is no conflict of interest.

Funding: This review has no fund.

Authors' contributions: IMZ has collected the data, and write the manuscript on its form.

Acknowledgements: Thanks are due to Dr. Hashem Abd El-Rahman, Animal Production Prof. \& NRCERS current executive supervisor, Dr. Mohamed F. El Karamany, Field Crop Prof. \& NRCERS former supervisor for their asset.

\title{
References
}

Abd El-Ghani M. M., El-Husseini M., El-Naggar S. I. 2008. Biogeography and diversity of the Tubiflorae in Egypt. Polish Botanical Journal, 53: 105-125.

Abd El-Ghani M. M., El-Sawaf N. 2004. Diversity and distribution of plant species in Agro-Ecosystems of Egypt. Systematics and Geography of Plants, 74(2): 319-336. http://www.jstor.org/stable/3668501.

Abd El-Ghani M. M., Salama F., Salem B., El-Hadidy A., Abdel-Aleem M. 2013. Biogeographical relations of a hyperarid desert flora in eastern Egypt. African Journal of Ecology, 52: 173-191. https://doi.org/10.1111/aje.12102.

Abd El-Ghani M. M., Salama F., Salem B., El-Hadidy A., Abdel-Aleem M. 2017. Phytogeography of the eastern desert flora of Egypt. Wulfenia, 24: 97-120. [Available at https://scholar.cu.edu.eg/sites/default/files/ monierabdelghani/files/phytogeography of the eastern desert flora of egypt wulfenia.pdf, Accessed 14 ${ }^{\text {th }}$ Oct, 2021].

Abdelaal M, Fois M, Fenu G, Bacchetta G. 2020. Biogeographical characterisation of Egypt based on environmental features and endemic vascular plants distribution. Applied Geography, 119: e102208. https://doi.org/10.1016/j.apgeog.2020.102208.

Abdul Maleque M., Maeto K., Ishii H.T. 2009. Arthropods as bioindicators of sustainable forest management, with a focus on plantation forests. Applied Entomology and Zoology, 44: 1-11. https://doi.org/10.1303/aez.2009.1

Abou-Awad B., Afia S. I., El-Saiedy E. S. 2017. Efficiency of two preadatory phytoseiid mites, biopesticide and fungal pathogen for controlling Tetranychus urticae Koch (Acari: Tetranychidae) on watermelon and muskmelon at Behera Governorate Egypt. Bioscience research, 14(4), 879-886. [Available at https://www.isisn.org/BR-14-2017/1042-1049-14(4)2017BR-1566.pdf]

Abou-Awad B.A., El-Sawaf B.M., Abdel-Khalek A.A. 2006. Four new species of eupodid mites from Egypt (Acari: Eupodoidea: Eupodidae). Acarologia, 46 (1-2): 43-52. [Available at https://www1.montpellier.inra.fr /CBGP/acarologia/article.php?id=1898]

Abou-Awad B.A., Hafez S. M., Afia S. I., Farahat B. M. 2016. Relationships of broad mite (Acari: Tarsonemidae) density to damage of apical pepper leaves and phytochemical components. International Journal of ChemTech Research, 9(7): 131-134. [Available at https://www.researchgate.net/publication/307018713] 
Adriansen H. K. 2009. Land reclamation in Egypt: A study of life in the new lands. Geoforum, 40: 664-674. https://doi.org/10.1016/j.geoforum.2009.05.006.

Adss I. A., Tabikha R. M. 2016. Relatedness among geographical populations of Sitobion avenae (fab.) (Hemiptera: Aphididae) in Egypt, based on screening of some morphological characters and mitochondrial-DNA COI gene analysis. Journal of Plant Protection and Pathology, Mansoura University, 7(7): 417 - 426. https://doi.org/10.21608/IPPP.2016.51041

Alfazairy A. A., El-Abed Y. M. G., Karam H. H., Ramadan H. M. 2020. Morphological characteristics of local entomopathogenic protozoan strains isolated from insect cadavers of certain stored-grain pests in Egypt. Egyptian Journal of Biological Pest Control, 30:7-20. https://doi.org/10.1186/s41938-020-0203-Z

Allan J. D., Flecker A. S. 1993. Biodiversity conservation in running waters: Identifying the major factors that threaten destruction of riverine species and ecosystems. BioScience, 43(1): 32-43. https://doi.org/10.2307/1312104

Bakry A. B., Nofal O., Zeidan M. S. 2012. Agronomic characteristics of three flax varieties as affected by some sources of potassium fertilization under newly reclaimed sandy soil conditions. Australian Journal of Basic and Applied Sciences, 6(4):77-81.

Bakry, B. A., Elewa, T. A., El Karamany M. F., Zeidan, M. S., Tawfik M. M. 2011. Effect of row spacing on yield and its components of some Faba bean varieties under newly reclaimed sandy soil condition. World Journal of Agricultural Sciences, 7 (1): 68 72. [Available at https://www.researchgate.net/publication/266566236]

Barker G., Efford M. 2004. Predatory gastropods as natural enemies of terrestrial gastropods and other invertebrates. pp 279-403. In: G. Barker (ed.). Natural Enemies of Terrestrial Molluscs. CAB International, Wallingford. https://doi.org/10.1079/9780851993195.0279.

Barreto C., Rillig M., Waldman W., Maaß S. 2021. How soil invertebrates deal with microplastic contamination. Frontiers for Young Minds. 9:625228. https://doi.org/10.3389/frym.2021.625228.

Behan-Pelletier V. M. 1999. Oribatid mite biodiversity in agroecosystems: role for bioindication. Agriculture, Ecosystems \& Environment, 74(1-3): 411-423. https://doi.org/10.1016/S0167-8809(99)00046-8.

Bonada N., Prat N., Resh V. H., Statzner B. 2006. Developments in aquatic insect biomonitoring: A Comparative analysis of recent approaches. Annual Review of Entomology, 51(1): 495-523. https://doi.org/10.1146/annurev.ento.51.110104.151124

Boulos, L. 2000. Flora of Egypt. Volume three, PP. 168-170. Printed by Al Hadara Publishing, Cairo, Egypt.

Cuny M. A. C., Bourne M. E., Dicke M., Poelman E. H. 2021. The enemy of my enemy is not always my friend: Negative effects of carnivorous arthropods on plants. Functional Ecology, 00: 1-11. https://doi.org/10.1111/1365- 2435.13884.

Deghiche-Diab N., Deghiche L., Belhamra M. 2020. Study of spontaneous plants and their associated arthropods in Ziban oases agroecosystem, Biskra-Algeria. IOBC-WPRS Bulletin, 151: 127-134.

Deghiche-Diab N., Deghiche L., Kachai S. 2016. Importance of spontaneous plants of steppe arid regions Ouled Djellel Biskra (Algeria). International Journal of Botany Studies, 1(3): 3-7.

Desoky A.S.S. 2018. Identification of terrestrial gastropods species in Sohag Governorate, Egypt. Archives of Agriculture and Environmental Science, 3(1): 45-48 https://doi.org/10.26832/24566632.2018.030105.

Dicke M., Sabelis M. W. 1987. How plants obtain predatory mites as bodyguards. Netherlands Journal of Zoology, 38(2-4): 148-165. https://doi.org/10.1163/156854288X00111.

Ebach M. C., Goujet D. F. 2006. The first biogeographical map. Journal of Biogeography, 33: 761-769. https://doi.org/10.1111/j.13652699.2006.01477.x.

El-Erksousy M. H., Heikal H. M., Abozid A. I. 2018. True spiders inhabiting date palm varieties with special reference to the biological aspects of Thanatus albini reared on Red Palm Weevil Rhynchophorus ferrugineus in Egypt. Menoufia Journal of Plant Protection, 3: 105-113. [Available at https://mjpam.journals.ekb.eg/article_123869 960f9f393cfcb2f2f59ef9a1a6201f9c.pdf] 
El-Laithy A.Y. M., Elseedy E. M., Hussein H. E. 2021. Efficacy of the predatory mite Cydnoseius negevi (Swirskii \& Amitai) (Acari: phytoseiidae) as a shared predator for sucking pests on sweet pepper in a net house in Egypt. Systematic and Applied Acarology, 26(10), 1856-1866. https://doi.org/10.11158/saa.26.10.3

El-Naggar M. E., Sallam G. M. 2000. Survey of true spiders associated with some field crops in Egypt. Proceedings of the Beltwide Cotton Conference, $\quad$ [Available at https://www.cotton.org/beltwide/proceedings/getPDF.cfm?year=2000\&paper=438.pdf]

EPA (U. S. Environmental Protection Agency). 2021. Climate change indicators: health and society. [webpage available at https://www.epa.gov/climate-indicators/health-society Accessed Feb 17th, 2021].

Eshra E. 2013. Survey and distribution of terrestrial snails in fruit orchards and ornamental plants at Alexandria and EL-Beheira Governorates, Egypt. Alexandria Science Exchange Journal, 34: 242-248. [available at: https://www.researchgate.net/publication/275466974].

FAO. 2021. The state of knowledge of soil biodiversity: Enter a hidden world. Digital report [Available at https://www.fao.org/resources/digital-reports/soil-biodiversity/en/, Accessed $13^{\text {th }}$ Oct, 2021].

Goldschmidt T. 2016. Water mites (Acari, Hydrachnidia): powerful but widely neglected bioindicators - A review. Neotropical Biodiversity, 2(1): 12-25. https://doi.org/10.1080/23766808.2016.1144359.

Haggag, W. M., Shabaan A. M., Nasr A. K., Abd El-Salam A. M. E. 2014. Integrated pest management for sustainable mango production. International Journal of Pharmaceutical Sciences Review and Research, 29(2): 276-282. [Available at http://globalresearchonline.net/journalcontents/v29-2/48.pdf]

Hammer Ø., Harper D.A.T., Ryan P.D. 2001. PAST: Paleontological Statistics Software Package for Education and Data Analysis. Palaeontologia Electronica, 4(1): 9pp. [available at http://palaeo-electronica.org/2001_1/past/issue1_01.htm].

Hassanein Bey A. M. 1925. The Lost Oases. American University of Cairo Press. Cairo and New York, 2006. Reissue of 1925 edition with introduction by Michael Haag. ISBN 978-977-424-980-8, pp. 316.

Heggy E., Sharkawy Z., Abotalib A. Z. 2021. Egypt's water budget deficit and suggested mitigation policies for the Grand Ethiopian Renaissance Dam filling scenarios. Environmental Research Letters, 16(7): 074022. https://doi.org/10.1088/17489326/ac0ac9.

Kaky E., Gilbert F. 2017. Predicting the distributions of Egypt's medicinal plants and their potential shifts under future climate change. PLoS ONE, 12(11): e0187714. https://doi.org/10.1371/journal.pone.0187714.

Kansara P., Li W., El-Askary H., Lakshmi V., Piechota T., Struppa D., Abdelaty Sayed M. 2021. An assessment of the filling process of the Grand Ethiopian Renaissance Dam and its impact on the downstream countries. Remote Sensing, 13(4):711. https://doi.org/10.3390/rs13040711.

McAleece N., Gage J.D.G., Lambshead P.J.D., Paterson G.L.J. 1997. BioDiversity: Professional statistics analysis software. Jointly developed by the Scottish Association for Marine Science and the Natural History Museum London. [available at https://www.sams.ac.uk/science/outputs/].

Meijer D., Meisenburg M., van Loon J. J.A., Dicke M. 2022. Effects of low and high red to far-red light ratio on tomato plant morphology and performance of four arthropod herbivores. Scientia Horticulturae, 292: 110645. https://doi.org/10.1016/j.scienta.2021.110645.

Nasr M. A. 2016. Predacious mites attacking pests infesting soybean and peanut at Menia and Behera Governorates, Egypt. MSc. Thesis, Faculty of Agriculture, Cairo University. 150 pp.

Omar M.E.M., Moussa A.M.A. 2016. Water management in Egypt for facing the future challenges. Journal of Advanced Research, 7(3): 403-412. https://doi.org/10.1016/j.jare.2016.02.005.

Orgiazzi, A., Bardgett, R.D., Barrios, E., Behan-Pelletier, V., Briones, M.J.I., Chotte, J-L., De Deyn, G.B., Eggleton, P., Fierer, N., Fraser, T., Hedlund, K., Jeffery, S., Johnson, N.C., Jones, A., Kandeler, E., Kaneko, N., Lavelle, P., Lemanceau, P., Miko, L., 
Montanarella, L., Moreira, F.M.S., Ramirez, K.S., Scheu, S., Singh, B.K., Six, J., van der Putten, W.H., Wall, D.H. (Eds.) 2016. Global soil biodiversity atlas. European Commission, Publications Office of the European Union, Luxembourg. 176 pp. [Available at https://www.globalsoilbiodiversity.org/atlas-introduction]

Orlofske, J. M. 2008. Terrestrial arthropod community and indicators of biotic integrity for Iowa tallgrass prairie. Retrospective Theses and Dissertations. 15391. 122 pp [available at https://lib.dr.iastate.edu/rtd/15391].

Polis G. A., Myers C. A., Holt R. D. 1989. The ecology and evolution of intraguild predation: potential competitors that eat each other. Annual Review of Ecology and Systematics, 20(1): 297-330. https://doi.org/10.1146/annurev.es.20.110189.001501.

Prather R.M., Castillioni K., Welti E.A.R., Kaspari M., Souza L. 2020. Abiotic factors and plant biomass, not plant diversity, strongly shape grassland arthropods under drought conditions. Ecology, 101(6): e03033. https://doi.org/10.1002/ecy.3033.

Salama I. A., El Husseini M. M., Tabikha R. M. 2016. Dispersal of Pteromalus puparum L. and Trichogramma evanescens, Parasitoids of Artogia rapae L. (Lepidoptera: Pieridae) in Cauliflower Fields, at El-Behera Governorate, Egypt. Egyptian Bulletin of Entomological Research, 82(2): 161-165. [Available at https://www.researchgate.net/publication/329359236]

Schausberger P. 2003. Cannibalism among phytoseiid mites: A review. Experimental and Applied Acarology, 29 : 173-191. https://doi.org/10.1023/A:1025839206394.

Sleem S.H., Hassan M. M. 2010. Impact of pollution on invertebrates biodiversity in the River Nile associated with Dahab and ElWarrak Islands, Egypt. International Journal of Environmental Science and Engineering (IJESE), 1: 15-25.

Stork N.E., Eggleton P. 1992. Invertebrates as determinants and indicators of soil quality. American Journal of Alternative Agriculture, (7): 38-47. https://doi.org/10.1017/S0889189300004446.

Tawfik M.M., Ahmed M.A., Bahr A.A., El Karamany M.F., Zeidan M.S. 2012. Saline irrigation management for sustainable use. pp 463-472. In: Leal Filho W. (eds) Climate change and the sustainable use of water resources. Climate Change Management. Springer, Berlin, Heidelberg. https://doi.org/10.1007/978-3-642-22266-5 29

Wall D. H., Nielsen U. N., Six J. 2015. Soil biodiversity and human health. Nature, 528: 69-76. https://doi.org/10.1038/nature157444.

Wang S., Brose U., Gravel D. 2019. Intraguild predation enhances biodiversity and functioning in complex food webs. Ecology 100(3): e02616. https://doi.org/10.1002/ecy.2616.

Wardle D. A. 2006. The influence of biotic interactions on soil biodiversity. Ecology Letters, 9: 870-886. https://doi.org/10.1111/j.1461$\underline{0248.2006 .00931 . x}$.

Wolff P. 1993. Land reclamation in Egypt. Der Tropenlandwirt-Journal of Agriculture in the Tropics and Subtropics, $94(2): 103-117$. [Available at https://www.jarts.info/index.php/tropenlandwirt/article/viewFile/979/284, Accessed 17th Oct, 2021] (In German).

Zeidan, M.S. 2007. Effect of organic manure and phosphorus fertilizers on growth, yield, and quality of lentil plants in sandy soil. Research Journal of Agriculture and Biological Sciences, 3(6): 748-752. [Available at http://www.aensiweb.net/AENSIWEB/rjabs/rjabs/2007/748-752.pdf] 